\title{
PRODUÇÃO DE ESTÓRIAS E O GOSTO DE AFAZER: EXERCÍCIOS DE IMAGINAÇÃO EM ESCRITA PARA A EDUCAÇÃO EM DIREITOS HUMANOS
}

\section{STORYTELLING AND THE PLEASURE OF GETTING USED TO: EXERCISES IN IMAGINATION FOR WRITING PRACTICE IN HUMAN RIGHTS EDUCATION}

\author{
Daniela Palma* \\ Ana Paula dos Santos de Sá** \\ Nayara Natalia de Barros ${ }^{* * *}$ \\ Rafael Salmazi Sachs ${ }^{* * * *}$
}

\section{RESUMO}

Os direitos humanos podem ser compreendidos como um conjunto de princípios que operam no plano formalizado da linguagem e também em um sistema de significação mais amplo, não formalizado. Este artigo apresenta uma proposta de formação em direitos humanos baseada na produção de estórias e voltada à educação escolar de jovens. Elaborada no âmbito do grupo de pesquisas em linguagem e direitos humanos (IEL/Unicamp), a proposição se baseia didática e pedagogicamente no pensamento de Hannah Arendt e almeja expor um projeto político de ensino viável, que enfoque a disciplina de Língua Portuguesa - sem ignorar seu potencial interdisciplinar - para a produção do que chamamos de "exercícios de imaginação" em escrita. Nossa proposta, portanto, tenciona promover reflexões, em sala de aula, acerca das conceituações jurídicas, filosóficas e subjetivas dos direitos humanos e das formas sociais da diferença e da universalidade, além de estimular, na escrita, inversões de perspectiva, adotando-se o "eu" como enunciador de um "outro". Tais inversões funcionariam como aparato propício à sensibilização e à busca de uma "mentalidade alargada", mais consciente da alteridade e apta à apreensão dos dilemas individuais e coletivos do mundo contemporâneo.

Palavras-chave: direitos humanos; educação; escrita; produção de estórias; Hannah Arendt.

\section{ABSTRACT}

Human rights can be understood as a set of principles operating on the formalized plane of language and also in a non-formalized system of meanings. This article presents a proposal for human rights education based on storytelling and focused on school education for young

\footnotetext{
* Universidade Estadual de Campinas, Campinas (SP), Brasil. dpalma@iel.unicamp.br

** Universidade Estadual de Campinas, Campinas (SP), Brasil. anap.ss88@gmail.com

${ }^{* * *}$ Universidade Estadual de Campinas, Campinas (SP), Brasil. nayara.natalia.barros@gmail.com

${ }^{* * * *}$ Universidade Estadual de Campinas, Campinas (SP), Brasil. rafael.sachs@gmail.com
} 
people. This proposition was elaborated within the scope of the research group on language and human rights (IEL/Unicamp) and based pedagogically and didactically on the thought of Hannah Arendt, it aims to expose a viable political teaching project for high school Portuguese classes, not ignoring the interdisciplinary potential in these so-called "exercises in imagination" in writing. Our proposal, therefore, intends to promote reflections, in the classroom, about the juridical, the philosophical and the subjective conceptions of human rights and social forms of difference and universality, as well as stimulating, in writing, inversions of perspective, adopting the "me" as the utterer of an "other". Such inversions would work as a propitious mechanism to sensitization and to the search for an "enlarged mentality," more aware of otherness and capable to apprehend the individual and collective dilemmas of the contemporary world.

Keywords: human rights; education; writing practice; storytelling; Hannah Arendt.

\section{INTRODUÇÃO}

Parte do título deste artigo foi retirada de uma palestra proferida pelo escritor Mia Couto, em junho de 2017, na Unicamp: "o grande prêmio que a literatura me dá (...) é o gosto de afazer. O gosto de afazer é um gosto de viajar pelos outros (...), ser outro". O verbo afazer, que descreve a ação de adaptar-se a um contexto, é usado aqui não como a fixação do estado de se sentir adaptado, mas como o encantamento pelo movimento constante de se habituar a um novo ambiente, uma nova terra, uma nova casa, uma nova roupa, uma nova língua, um novo corpo. Na visão do escritor, o gosto propiciado pela escrita literária não é o de assentar-se, mas o de estar em frequente adaptação, alargando a própria visão de mundo.

Assim, a literatura, na experiência da escrita, pode ser compreendida como o movimento de tornar presente o que está ausente (atividade da imaginação) e familiar o que é estranho (atividade do pensamento), enfatizando-se a ação de tornar, o momento da transição. A escrita é entendida, então, como gesto de transpassar limites geográficos, temporais, sociais e psicológicos. É tal compreensão que apoia a proposta, aqui apresentada, de uma formação em direitos humanos com base na produção de estórias, no âmbito da educação escolar de jovens, como esforço de prover espaços para reflexão e sensibilização em temas relacionados aos direitos humanos, à diversidade e à cultura da paz. Partimos, para tanto, da percepção de que essas questões, muito imprecisas para serem trabalhadas em termos exclusivamente conceituais, podem ter na criação de estórias um caminho de ampliar as possibilidades de apropriação de noções que permitam lidar melhor com sentimentos de alteridade.

Norberto Bobbio, a respeito da crise na fundamentação desses princípios, afirma que "o problema fundamental em relação aos direitos do homem, hoje, 
não é tanto o de justificá-los, mas o de protegê-los. Trata-se de um problema não filosófico, mas político" (BOBBIO, 2004, p. 16), compreensão também reforçada por Lynn Hunt, para quem "os direitos humanos só se tornam significativos quando ganham conteúdo político", ou seja, quando são entendidos não como "direitos de humanos em um estado de natureza", mas como "direitos de humanos em sociedade" (HUNT, 2009, p. 19). Assim, entendemos que a educação para os direitos humanos deve ser mais voltada para a ação do que fundada em conceitos genéricos e estáveis, ou posturas contemplativas. Compreendemos que o objetivo principal de um processo formativo nesse campo não é o de convencer de que os direitos humanos, em si, são bons ou maus, mas o de ressaltar que são princípios filosóficos e jurídicos, construídos historicamente, necessários na ordenação do mundo contemporâneo e relacionados a questões concretas das vidas cotidianas de todas e todos nós.

Foi a partir da obra de Hannah Arendt que encontramos possibilidades para pensar uma tal pedagogia, que articulasse a imaginação literária, a experiência política contemporânea e o pensamento conceitual com os sentidos das existências particulares.

\section{UM POUCO DO PERCURSO}

Ao mesmo tempo em que se observa grande centralidade da educação em direitos humanos em diversos documentos de políticas educacionais, também parecem ser frequentes algumas inquietações, por profissionais de ensino em vários campos disciplinares, sobre as dificuldades em encontrar recortes temáticos e metodologias para tratar pedagogicamente a questão. Esse foi um dos pontos de partida de nosso grupo de pesquisa: pensar formas de contribuir para a formação em direitos humanos de jovens a partir dos espaços da educação linguística e literária.

A ideia de trabalhar com a escrita de narrativas nasceu, propriamente, da leitura de um artigo de Celso Lafer (2007), a respeito de três cursos de Arendt. Além de ter sido aluno de um deles - a disciplina de pós-graduação Fall Term de 1965, "Political Experiences in the Twentieth Century", na Universidade de Cornell - Lafer (2007) também cita o curso de pós-graduação (de mesmo nome) do Spring Term de 1968, na New School for Social Research, e o de graduação do Spring Term de 1955, "Contemporary Issues", na Universidade de Berkeley. Recorrendo às suas próprias anotações de estudante, aos roteiros de aula de Arendt (depositados na divisão de manuscritos da Biblioteca do Congresso dos Estados Unidos), e à obra da autora como um todo, o artigo aponta que Arendt propunha a seus alunos a criação do que 
chamava de exercises in imagination: a dinâmica de escrita da biografia imaginária de uma pessoa nascida na última década do século XIX, com o objetivo epistemológico de "discutir em que medida as teorias contemporâneas refletem ou são adequadas para lidar com as experiências políticas centrais do século XX" (LAFER, 2007, p. 293).

Posteriormente, tomamos contato com a proposta de um ciclo de oficinas que articulava tais proposições de Hannah Arendt a atividades de escrita criativa. Intitulado "A narrativa revela o sentido sem cometer o erro de defini-lo", o ciclo era promovido pela cátedra Unesco de Educação para Paz, Direitos Humanos, Democracia e Tolerância. Foi realizado em duas edições no ano de 2014 (no Centro Universitário Maria Antônia e na Faculdade de Direito da USP, ambos na cidade de São Paulo), destinado a jornalistas, advogados, procuradores, professores e estudantes de direito $3 / 4$ nas palavras das idealizadoras, um público de "pessoas familiarizadas com os discursos sobre direitos humanos e que tinham muito prazer em ler e escrever" (RÜSCHE; MASCARO, 2015, p. 81).

Com base nessas referências, passamos a pensar, então, uma concepção pedagógica geral e formatos de atividades didáticas específicas voltadas ao público escolar, este, por sua vez, sem formação específica nessa área nem discursos uníssonos sobre as questões desse campo. Articulamos, assim, uma proposta de "sensibilização" para os direitos humanos à preocupação com a formação em linguagem, especificamente por meio da escrita de estórias.

\section{PENSAR COM HANNAH ARENDT UMA PEDAGOGIA PARA OS DIREITOS HUMANOS}

Como o pensamento de Hannah Arendt pode apoiar didática e pedagogicamente uma proposta de formação em direitos humanos? Tal questão inicial orientou nossa busca por uma fundamentação que apontasse não para conceitos, mas para possibilidades de ação - uma espécie de "como fazer" fundante para um projeto político de ensino. O pensamento de Arendt é fundamental nos estudos sobre direitos humanos, mas como se apropriar dele para pensar o ensino e, mais especificamente, o ensino da linguagem? Começamos por abordar a figura de Hannah Arendt professora, em vez da filósofa ou cientista política - justamente um dos pontos que Lafer (2007) destaca em seu artigo. O autor observa que alguns dos principais estudiosos da obra de Hannah Arendt foram alunos dela e, assim como ele próprio, declararam-se impactados pela "experiência única de ouvir de viva voz o pensamento" de sua professora (LAFER, 2007, p. 291). 
Segundo Peter Stern e Jean Yarbrough, alunos na New School for Social Research, Arendt conseguia ir muito além da habilidade de apresentar ideias de forma vívida e envolvente: ela podia tornar tangíveis e reconhecíveis aos alunos experiências que não eram as deles, despertando-lhes certo "senso de realidade": "nas mãos dela, as ideias não eram meros degraus na construção de um argumento ou abstrações alienadas da experiência, mas a essência absoluta da experiência destilada na língua do pensamento conceitual" (STERN; YARBROUGH, 1978, p. 372)1. Jerome Kohn, que frequentou o curso da New School, conta que indagava por que, em pleno 1968, na ebulição das movimentações estudantis, Arendt escolheu evocar em sua disciplina guerras e revoluções da primeira metade do século XX e relembra a proposta dos exercises in imagination:

(...) Arendt tencionava que seus estudantes pudessem experienciar de modo vicário o que a geração dela havia conhecido diretamente: um tempo em um passado não tão distante quando a política encenava a si em um encadeamento de ações e reações de extrema violência. $\left(\mathrm{KOHN}_{;}\right.$YOUNG-BRUEHL, 2006, p. 220) ${ }^{2}$

Outra aluna, colega de turma de Kohn em 1968 e posteriormente biógrafa de Arendt, Elisabeth Young-Bruehl, relembra esse curso e a proposta de produção da biografia imaginária como chave para ela própria conseguir pensar e se situar no contexto em que estava vivendo naquele momento.

\begin{abstract}
Naquela época, eu acho que aprendemos com Arendt o quão crucial é, em 'tempos sombrios', que existam pessoas que consigam não ser tragadas pela cascata de eventos do cotidiano, momento a momento, dia a dia, ano a ano, ou pelos sentimentos que esses eventos em cascata induzem: sentimentos de desamparo e desesperança; sentimentos que conduzem as pessoas a querer uma solução rápida, um remédio e uma norma a seguir, uma explicação e também um comando subtraído de explicação. Nós aprendemos como é difícil fazer isso que Hannah Arendt chamou de maneira muito simples de 'pare e pense'. Quando falávamos de política, como estamos fazendo agora, nós deveríamos produzir, pelo menos para nós mesmos, o espaço e tempo de 'parar e pensar' e isso deveria nos trazer felicidade - aquela felicidade peculiar dos cidadãos, evocada por nossa Constituição. (KOHN, YOUNG-BRUEHL, 2006, p. 223$)^{3}$
\end{abstract}

1. "In ber bands, ideas were not simply steps in an argument, or abstractions divorced from experience, but the very essence of experience distilled into the language of conceptual thought". [Todas as traduções são nossas.]

2. "(..) Arendt was intent that ber students vicariously experience what ber generation bad known immediately: a time in the not distant past when politics had played itself out in a concatenation of actions and reactions of extreme violence".

3. "At that time, I think we learned from Arendt how crucial it is in 'dark times' that there be people who do not get swept up in the moment-to-moment, day-to-day, year-to-year cascade of events, or in the feelings that cascading events, out-of-control events, induce: feelings of belplessness and desperation, feelings that lead people to want a quick solution, a remedy, and a rule to follow, an explanation and a command deduced from the explanation. We learned bow bard it is to do the thing Arendt named very simply 'stop and think'. When we talked politics, then as now, we would produce for ourselves, at least, the space and time to 'stop and think,' and it would bring us bappiness — that peculiar bappiness of citizens, which our Constitution invokes". 
Nesses relatos de ex-alunos, enfatiza-se a memória tanto das experiências das aulas em si (diretamente vivenciadas pelos estudantes), como a construção de espaços para a criação imaginativa de experiências políticas situadas como eventos históricos, em um passado mais ou menos recente, tematizados nas ementas dos cursos. A possibilidade de tocar a experiência, mesmo a não vivida pelos estudantes, dava-se por uma sensibilidade literária preocupada em "capturar o significado por meio de imagens e narrativas" (STERN, YARBROUGH, 1978, p. 372)4 , articulada a uma "mente filosófica", amparada na argumentação lógica. Assim, "parte do sucesso dela [Arendt] como professora, repousava em seu 'dom para pensar poeticamente', uma expressão que ela própria usou para descrever o modo de pensar de Walter Benjamin" (STERN; YARBROUGH, 1978, p. 37)5. Em suas aulas, lia-se e escreviase literatura, juntamente com referências filosóficas e historiográficas.

Young-Bruehl descreve Arendt como uma contadora de histórias e uma colecionadora: apaixonada pelo storytelling e com um "indefectível olhar para a vida das estórias" ${ }^{\prime \prime}$, Arendt recolhia estórias, dizeres, citações e imagens que usava como "os fios com os quais alinhavava suas falas e seus trabalhos" ${ }^{17}$ (YOUNGBRUEHL, 1977, p. 183). A associação entre tecer e narrar (ou contar estórias) remete justamente ao mito da tecelã, usado por Arendt para representar a mecânica da faculdade do pensar: o "pensamento é como a teia de Penélope, desfaz-se toda manhã o que se terminou de fazer na noite anterior" (ARENDT, 1995, p. 69).

Em Arendt, pensamento e cognição são faculdades distintas. O conhecimento, interesse da cognição, volta-se para a fabricação do mundo, funda-se em objetivos utilitários e tenciona resultados verificáveis. Já o pensamento é compreendido como a capacidade de refletir sobre as coisas e as experiências, ajuda-nos a descobrir e desenhar nossa pertença no mundo. Pensar não é buscar resultados definitivos: "a necessidade da razão não é inspirada pela busca da verdade, mas pela busca do significado. E verdade e significado não são a mesma coisa" (ARENDT, 1995, p. 14): significados são instáveis, a cada dia é preciso desfazer a trama de sentidos e tecê-la novamente, de modo que o pensamento não seja o fim, mas sim o processo de tessitura. Essa busca por sentidos estaria em falta em uma época pesadamente utilitarista, pois "a utilidade, quando promovida a significância, gera ausência de significado" (ARENDT, 2005, p. 167). A ausência de pensamento se configuraria

\footnotetext{
4. "Literary sensibility is usually concerned with capturing meaning through imagery and narrative (...)".

5. "Part of ber success as a teacher, then, lays in ber 'gift of thinking poetically', an expression she berself used to describe Walter Benjamin's mode of thought".

6. "(...) unfailing regard for the life of the story".

7. "Her stories and ber sayings were the threads with which she wove her conversations and ber works".
} 
como "uma experiência tão comum em nossa vida, em que dificilmente temos tempo e muito menos desejo de parar e pensar" (ARENDT, 1995, p. 6).

Em seu ensaio "A crise na educação", que faz parte de Entre o passado e o futuro, Hannah Arendt aponta, no contexto da década de 1950, que as próprias escolas ajudaram a esvaziar os espaços do pensamento, substituindo o aprendizado pelo fazer (entendido não como uma ação iniciadora de processos, mas como um conjunto de atividades reprodutoras de procedimentos). A função da escola teria se reduzido a fornecer ferramentas que permitissem o desenvolvimento de habilidades para produzir resultados. Um modelo de educação oferecido como tão inovador que acabava por suprimir a possibilidade de as crianças e os jovens serem, por si mesmos, semente de inovações e transformações:

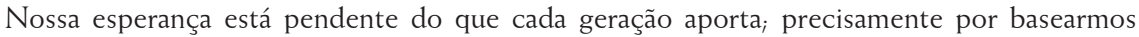
nossa esperança apenas nisso, porém, é que tudo destruímos se tentarmos controlar os novos de tal modo que nós, os velhos, possamos ditar sua aparência futura. Exatamente em benefício daquilo que é novo e revolucionário em cada criança é que a educação precisa ser conservadora; ela deve preservar essa novidade e introduzi-la como algo novo em um mundo velho, que, por mais revolucionário que possa ser em suas ações, é sempre do ponto de vista da geração seguinte, obsoleto e rente à destruição. (ARENDT, 1972, p. 243)
\end{abstract}

O conhecimento, como um elenco de técnicas e habilidades, teria um caráter muito mais reprodutor, logo, limitado em seu potencial subversivo, e a subversão é essencial para que as novas gerações possam inserir "algo novo em mundo velho". Educar, afirma Arendt, é "assumir a responsabilidade coletiva pelo mundo" (ARENDT, 1972, p. 239), e o caminho pelo qual ela própria, educadora, tanto em sua atuação docente como em seus escritos, envereda é o de propiciar espaços para o pensamento. "Pare e pense", um comando simples para habilitar pensamentos sem comandos, o incentivo a seus alunos para que eles pudessem pensar without a banister, "sem o apoio do corrimão de conceitos seguros" (LAFER, 2007, p. 293), saindo em busca de sentidos, não de verdades - como ela mesma fez em sua cobertura do julgamento de Eichmann em Jerusalém.

Narrativa e ação. A narrativa está na base desse "pensamento sem corrimão": "o contar história revela o sentido sem cometer o erro de defini-lo", afirma Arendt na biografia de Isak Dinesen, que compõe Homens em tempos sombrios (ARENDT, 1987, p. 78). No prefácio de Entre o passado e o futuro, ela aponta a importância dos efeitos de sentido que os eventos narrados têm na mente de quem conta a estória e descreve o funcionamento desse movimento do pensamento:

Caso fosse preciso escrever a história intelectual do nosso século, não sob a forma de gerações consecutivas, onde o historiador deve ser fiel à sequência de teorias e atitudes, mas como uma biografia de uma única pessoa, não visando senão a uma aproximação metafórica do que 
ocorreu efetivamente na consciência dos homens, veríamos a mente dessa pessoa obrigada a dar uma reviravolta não uma, mas duas vezes: primeiro, ao escapar do pensamento para a ação, e a seguir, quando a ação, ou antes, o ter agido, forçou-a de volta ao pensamento. (ARENDT, 1979, p. 35, grifos nossos)

No trecho acima, há a síntese da formulação que embasa a proposta de seus cursos. Nas anotações no roteiro de aula do curso de Cornell, Arendt indaga: "Se a história não é feita por homens em ação, ela é feita, então, por historiadores?" (apud LAFER, 2007, p. 294) ${ }^{8}$. Ficam explícitas as articulações entre discurso e vida ativa. A ação juntamente com o discurso são as atividades que nos inserem no mundo; para Hannah Arendt, em A condição bumana, são elas que criam a distinção que nos define como seres singulares entre iguais: identidade e diferença como duplo aspecto a configurar a pluralidade humana. É na ação e no discurso que os seres humanos se distinguem e se manifestam uns aos outros. Para a autora, agir equivale a iniciar algo e enunciar, a revelar o sujeito, duas atividades que são interdependentes na configuração do pensamento: "sem a revelação do agente no ato, a ação perde seu caráter específico e torna-se um feito como outro qualquer. Na verdade, passa a ser apenas um meio de atingir um fim, tal como a fabricação é um meio de produzir um objeto" (ARENDT, 2005, p. 193). A ação desarticulada do discurso revelador do sujeito corresponderia à "'opacidade triste' de uma vida centrada apenas em si mesma" (ARENDT, 1979, p. 29).

Julia Kristeva observa que Hannah Arendt compreende a "vida humana como uma ação política revelada na linguagem de uma narração (estória e história)" (KRISTEVA, 2001, p. 13). É nessa linguagem narrativa, então, que acontece a revelação do sujeito, cuja ação inicia algo e que é capaz de pensar, querer e julgar.

\footnotetext{
No momento em que desejamos dizer quem alguém é, nosso próprio vocabulário nos induz ao equívoco de dizer o que esse alguém é; enleamo-nos numa descrição de qualidades que a pessoa necessariamente partilha com as outras que lhe são semelhantes; passamos a descrever um tipo ou 'personagem' na antiga acepção da palavra, e acabamos perdendo de vista o que ela tem de singular e específico. (ARENDT, 2006, p. 194)
}

Então, só seria possível revelar quem alguém é por meio da "história da qual ele é herói", de sua biografia, um herói revelado que "não precisa de qualidades heroicas" (ARENDT, 2005, p. 199) e nem ser assentado em campos de moralidades fixas; a revelação do herói é caminho para lermos as singularidades em meio aos grandes processos históricos, o singular em suas instabilidades, em suas contradições, em suas fissuras.

8. "If bistory is not made by acting men, is it made by bistorian?"

9. "Arendt's concept of buman life as a political action revealed in de language of a narration (story and bistory)". 
Imaginação e experiência. Pensamento, narrativa e experiência "estão indissoluvelmente interligados" nos cursos de Hannah Arendt e baseiam a compreensão de que "as teorias, por mais abstratas que sejam ou pareçam, têm atrás de si estórias e incidentes que contêm in nuce o que temos a dizer" (LAFER, 2007, p. 290). A experiência é a ação revelada pela linguagem da narração, a estória que precede a história. A estória, afirma Arendt, "registra, em sua extrema simplicidade e coesão, um fenômeno mental, algo que se poderia denominar um evento-pensamento." (ARENDT, 1979, p. 36).

O evento-pensamento é a localização de uma espécie de pensamento-antesda-teoria, momento do trabalho imaginativo da narração de eventos, a partir do qual novos pensamentos teóricos podem vir a ser formulados. É o pensar-ação, um vir-a-ser-teoria, perpassado por relações tempo-espaciais, situado entre a memória e as projeções ou antecipações - o passado e o futuro que atuam como forças sobre essa forma de pensar e agir. Retornar a esse momento pré-teórico era a proposta de Hannah Arendt para seus alunos por meio dos exercícios de compor biografias imaginárias, explorando as relações entre estória e história. Esse procedimento de destacar uma existência para compor um processo funciona como metáfora, cuja construção depende da faculdade da imaginação.

A compreensão da imaginação em Hannah Arendt vem do diálogo que ela estabelece com a teoria do conhecimento de Kant. Em sua leitura, a imaginação para Kant é a faculdade de "tornar presente ao espírito o que está ausente da percepção sensível" (ARENDT, 1994a, p. 102) e opera pela síntese da sensibilidade ou intuição (campo da experiência) com o conhecimento, da imagem com o conceito. A intuição fornece o particular, o conceito torna esse particular comunicável: "na percepção desta mesa particular está contida a 'mesa' enquanto tal. Desse modo, nenhuma percepção é possível sem imaginação" (ARENDT, 1994a, p. 105), que opera pela produção de formas esquemáticas que permite perceber o universal no particular.

Nos cursos em que Hannah Arendt propôs os exercises in imagination, ela orientava que a biografia imaginária deveria focar um personagem nascido no fim do século XIX, a ser caracterizado não como equivalente aos protagonistas das narrativas historiográficas dos contextos em questão, nem como mero observador, mas alguém sobre quem os eventos narrados incidissem e que, de alguma maneira, a eles reagisse. Outro parâmetro para construir as biografias era o de que o protagonista da estória deveria passar pela experiência de certos eventos históricos demarcados, chamados por Arendt de guide posts. Os significados desses eventos sinalizados deveriam ser trazidos à tona "com base na multiplicidade das experiências políticas 
do século XX e nas correspondências que desvendou a partir de textos selecionados nas bibliografias" (LAFER, 2007, p. 299). Nessa dinâmica, a relação entre guide posts e biografia imaginária equivale à relação entre história e estória, construída como movimento em escapadas: o pensamento parte da história escapa para estória, cujo fio de condução por sua vez permite escapadas frequentes aos parâmetros da história, estabelecendo uma relação contínua entre o particular e o universal.

Sobre as implicações dessa relação, Arendt chama a atenção no prefácio de seu livro de biografias, Homens em tempos sombrios, para o fato de que as narrativas ali contidas não se apresentam como "porta-vozes do Zeitgeist", apenas como referências ao modo pelo qual algumas pessoas "se moveram pelo mundo e como foram afetadas pelo tempo histórico" (ARENDT, 1987, p. 4). Jerome Kohn observa que, para Hannah Arendt, pensar sobre os eventos do passado não era um simples meio de evitar que eles se repetissem no futuro. Era um caminho para compreender "que o presente se tornou o que realmente é, um mundo no qual um novo começo é sempre possível, mas que isto é sempre condicionado a uma tomada de responsabilidade pelas circunstâncias, não de maneira pessoal, e sim política" (KOHN, YOUNGBRUEHL, 2006, p. 223) ${ }^{10}$.

Sair em visita. A seleção dos guide posts era fundamental para exercitar a imaginação dos estudantes no sentido de proporcionar um espaço para refletir politicamente sobre experiências que não pertenciam a eles, de modo que havia um descolamento entre autor e biografado, dado que a experiência do biografado é diegética na dimensão da estória, enquanto a experiência do autor situa-se na prática do storytelling ${ }^{11}$, um presente que é invadido por efeitos de sentidos de uma experiência coletiva, historiograficamente construída e situada em uma ideia de passado. Esse descolamento era essencial para propiciar um insight, conforme a anotação no roteiro do curso da New School:

Quanto mais as pessoas forem capazes de pensar no lugar de outrem, mais elas serão capazes de re-presentar, de tornar presente em si o que de si está ausente. A virtude de um pronunciamento chamado insight. Isso não é empatia. Você não consegue sentir o que os outros sentem, mas imaginar, por meio da aprendizagem dos sentimentos, pensamentos etc. alheios, como você poderia sentir, pensar etc. [naquela situação, naquele corpo etc.]. Você pensa o seu próprio pensamento, mas no lugar de outra pessoa. Apenas pensando os seus

10. "I believe that for Arendt the importance of elucidating the past lay in showing that the present bas become what in reality it is, a world in which a new beginning is always possible but also is always conditional on taking not personal but political responsibility for the circumstances".

11. Isso não tem relação com possíveis confusões entre narrador da estória e autor, é mais sobre uma postura autoral na prática proposta nos exercises in imagination que aponta para o ethos de um autorcontador-de-história. 
próprios pensamentos, você vai poder realmente experienciar [o pensamento do outro], mas de uma maneira mediada, vicariamente. (apud LAFER, 2007, p. 300) ${ }^{12}$

Então, um dos objetivos principais desses exercícios era o de proporcionar espaços para a experiência vicária, o que, ainda no diálogo com Kant, Arendt chamou de "sair em visita", buscar ler o mundo de outras perspectivas, sem apenas se escorar em fixos corrimãos conceituais, morais e ideológicos da sua própria experiência. Em seu diálogo com Kant, compreende que "pensar com a mentalidade alargada significa treinar a própria imaginação para sair em visita" (ARENDT, 1994a, p. 57). $\mathrm{O}$ alargamento da mentalidade acontece quando desenvolvemos um sensus communis, uma consciência comunitária (mas que opera na mente de um indivíduo concreto e não em um coletivo abstrato), que é a própria capacidade de julgar. Ao sair em visita - algo passível de traçar paralelos ao que Mia Couto, no comentário citado no início deste artigo, chamou de "viajar pelo outro" em seu processo de escrita ou ainda das viagens xamânicas nas cosmologias ameríndias, aqui em uma chave que não é a da racionalidade ocidental -, podemos comparar nosso juízo com "outros juízes possíveis", de modo que ele possa ser constantemente reavaliado e reformulado. Reafirma que o sensus communis, para Kant, deve se basear em três máximas: "pense por si mesmo (a máxima do Iluminismo); ponha-se, em pensamento, no lugar de qualquer outro (a máxima da mentalidade alargada); e a máxima da consistência: esteja de acordo consigo mesmo" (ARENDT, 1994a, p. 91).

Nesses pontos do pensamento de Arendt, apresentados aqui de maneira condensada, encontramos caminhos para articular uma proposta de formação em direitos humanos com base na produção de estórias. Uma proposta que tenha uma dimensão política, não como mera tematização, mas um "como fazer" de natureza política. Esse "como fazer" relaciona-se aqui diretamente com a busca por formas de pensamento libertário (liberdade não como um absoluto, mas como gradações possíveis), ou mais precisamente exercícios para formas libertárias de linguagem, que possibilitem trabalhar a nossa faculdade do julgamento (a capacidade de comparar juízos). O caminho delineado para esse alargamento de mentalidades passa pelo trabalho imaginativo (pensar por metáforas), pela coleção e criação de estórias e imagens que nos permitam, no jogo perspectivo, tocar (imaginativamente) experiências que não são as nossas. Acionar a prática do "sair em visita" como

12. "The more people you are able to think in the place of, the more you will be able to re-present, to make present in your own person while they are absent. The virtue of the statement called Insight. This is not empatby. You are not supposed to feel as they felt but to imagine through learning of their 'feelings', thinking, etc. bow you would bave felt, thought, etc. You think your own thoughts but in the place of somebody else. Only if you think your own thoughts can you actually experience, though still in a mediated fashion-vicariously." 
meio para a busca de conhecimento seria então uma forma de exercitar também a escuta, compreendida não como atividade muda e passiva, mas exercida de modo ativo, criativo e dialógico, possibilitando a transformação das mentalidades e desenvolvimento de um senso comunitário muito mais aguçado.

$\mathrm{Na}$ sequência, apresentamos um quadro de políticas e ações de educação em direitos humanos no Brasil (e algumas iniciativas fora do país), com as quais também dialogamos na formulação da presente proposta, e ainda algumas considerações e estudos sobre o ensino e as práticas da escrita de narrativas em sala de aula.

\section{EDUCAÇÃO EM DIREITOS HUMANOS NO BRASIL: POLÍTICAS E DOCUMENTOS}

No Brasil, há alguns documentos que vêm instruindo o trabalho políticopedagógico no campo dos direitos humanos, os quais retomamos brevemente nesta seção.

O Plano Nacional de Educação em Direitos Humanos (PNEDH), lançado em 2003, é o principal documento a fornecer diretrizes educacionais no tema. Em consonância com a Constituição Federal de 1988 e com a Lei de Diretrizes e Bases da Educação Nacional de 1996, busca situar a questão dos direitos humanos no contexto escolar, fornecendo tanto orientações teóricas quanto práticas. Em síntese, suas linhas de ação abrangem desde a universalização e a qualidade da educação até a necessidade de dar atenção às especificidades das minorias, entre elas as comunidades indígenas e quilombolas e os estudantes com necessidades educacionais especiais. Assim, ressalta-se em sua introdução que "a educação em direitos humanos, sobretudo no âmbito escolar, deve ser concebida de forma articulada ao combate do racismo, sexismo, discriminação social, cultural, religiosa e outras formas de discriminação presentes na sociedade brasileira" (BRASIL-SEDH, 2003, p. 17).

Dez anos após a instituição do Plano, em 2013, publica-se o Caderno de Educação em Direitos Humanos - Diretrizes Nacionais $(\mathrm{CEDH})$, texto voltado não apenas à consolidação do $\mathrm{PNEDH}$, mas igualmente à divulgação e rememoração das Diretrizes Nacionais para a Educação em Direitos Humanos (DNEDH), aprovadas em 2012, e de outras iniciativas e políticas da área, como o Programa Nacional dos Direitos Humanos (PNDH), lançado em três versões (1996, 2002 e 2010). O Caderno, além da revisão histórica nacional e internacional sobre o lugar ocupado e conquistado pelos direitos humanos, reitera o papel da educação na prevenção e no enfrentamento da violação desses direitos por meio da formação de uma consciência crítica dos jovens:

Uma das concepções trazidas pelas Diretrizes Nacionais para a Educação em Direitos Humanos é a da educação para a mudança e a transformação social. Essa transformação proposta está 
relacionada a fazer com que o sujeito possa realizar uma nova interpretação de sua existência, tornando-se livre das violações e dos preconceitos que permeiam o seu ambiente, como, por exemplo, as desigualdades, a violência e a discriminação. (BRASIL-SDH, 2013, p. 42)

Assim, tanto o CEDH quanto o PNEDH destacam a presença de duas linhas de discursos recorrentes nas políticas educacionais: de um lado, o discurso pautado em uma ênfase no plano jurídico e racional, que trata os direitos humanos sob o viés político e universalizante - "a expressão direitos humanos é utilizada em referências a princípios universais que podem, potencialmente, ser aceitos por todas as culturas" (BRASIL-SDH, 2013, p. 16) -, de outro, aquele que os aproxima do plano mais subjetivo, discurso este que, ao condenar os preconceitos e as discriminações, reconhece os direitos como parte integrante tanto da construção e do exercício da cidadania quanto da formação das identidades e das subjetividades dos sujeitos, vinculando-os à conscientização e à sensibilização da sociedade.

De modo geral, tais discursos dialogam com os dois campos principais de significados atribuídos historicamente aos direitos humanos: uma linha de compreensão moderna do direito natural, ancorada principalmente no pensamento de base liberal, e que encontra fundamento nos princípios da igualdade e da universalização ("somos todos iguais, o direito nos reconhece como iguais"), outra, na perspectiva pós-moderna, em que se verifica a um reforço à aceitação das diferenças e dos direitos culturais e das minorias ("cada indivíduo tem o direito de ser diferente"). A primeira acepção relaciona-se aos termos da cultura da paz e da internacionalização; a segunda estaria mais diretamente ligada à noção de diversidade. Ao situar essas concepções historicamente, é necessário fazer as ressalvas de que o direito à diferença, como observa José Lindgren Alves, não deve ser considerado propriamente uma invenção da pós-modernidade, pois subjaz a todas as formulações modernas sobre a igualdade (ALVES, 2013, p. 14); segundo, de que a ideia de uma cultura da paz internacionalizada, na interpretação de Moyn, ganhou formatação mais consolidada apenas a partir das últimas décadas do século XX (MOYN, 2012).

Para os fins da nossa proposta de produção de estórias, interessa-nos explorar as duas vertentes (a jurídica e a identitária), sem culminar, porém, em um debate restrito a situações de violação desses direitos, um lugar-comum ao se explorar o tema. Embora esse recorte seja fundamental, principalmente em um país marcado por acentuada desigualdade social, é importante que os estudantes compreendam os seus sentidos para além dos contextos de violência. Trabalhar a formação para os direitos humanos a partir também de representações positivas é, pois, um dos objetivos (e desafios) do presente trabalho. 
Do ponto de vista curricular e pedagógico, a criação de textos narrativos dialoga com o ensino de português (nos eixos de leitura e de escrita) e com as orientações e as diretrizes para um ensino de base interdisciplinar em geral. $\mathrm{Na}$ Base Nacional Comum Curricular (BNCC) da Educação Infantil e do Ensino Fundamental ${ }^{13}$, divulgada em 2017, o papel atribuído à educação e à leitura literárias, por exemplo, mostra-se favorável a atividades que levem os jovens a uma reflexão acerca de si e do outro: "se a leitura literária possibilita a vivência de mundos ficcionais, possibilita também ampliação da visão de mundo, pela experiência vicária com outras épocas, outros espaços, outras culturas, outros modos de vida, outros seres humanos" (BRASIL-MEC, 2017, p. 65). Também nas Orientações Curriculares para o Ensino Médio (OCEM) de "Linguagens, Códigos e suas Tecnologias", publicadas em 2006, encontramos diretrizes similares: "(..) buscam-se práticas que propiciem a formação humanista e crítica do aluno, que o estimulem à reflexão sobre o mundo, os indivíduos e suas histórias, sua singularidade e identidade" (BRASILMEC, 2006, p. 33). Em relação especificamente à atividade de escrita criativa, merecem destaque as indicações presentes na última versão da BNCC do Ensino Médio, publicada em abril de 2018. Nela, para além de se reiterar a importância da promoção e do respeito aos Direitos Humanos na Educação, ressalta-se o papel de oficinas, em geral, e de oficinas de escrita criativa, em particular, no contexto de promoção de "situações de trabalho mais colaborativas, que se organizem com base nos interesses dos estudantes e favoreçam seu protagonismo", bem como a interdisciplinaridade (BRASIL-MEC, 2018, p. 472).

No plano das práticas pedagógicas que fundamentam nossa proposta, tal incentivo à interdisciplinaridade $e$, concomitantemente, à intertextualidade consolida-se, justamente, como um ponto forte do programa de escrita por nós sugerido. A exemplo do que propõem os Parâmetros Curriculares Nacionais (PCN) para o trabalho a ser realizado com seus Temas Transversais (a saber, Ética, Pluralidade Cultural, Meio Ambiente, Saúde, Orientação Sexual, Trabalho e Consumo), entendemos que a questão dos direitos humanos, em sentido mais amplo, também favorece o desenvolvimento de "um trabalho integrado de várias áreas" (BRASILMEC, 1998, p. 40), uma vez que demanda conhecimentos de viés geográfico, histórico, numérico etc. Nesse cenário de pluralidade de saberes, ganha relevância também a diversidade de gêneros textuais, a qual pode propiciar, no momento das atividades de pré-escrita, um melhor entendimento das esferas sociais, dos interlocutores e dos recursos linguísticos que integram os discursos e o exercício

13. A publicação da versão final da BNCC do Ensino Médio foi adiada devido à recente aprovação da Reforma do Ensino (lei n $\left.{ }^{\circ} 13.415 / 2017\right)$. 
da cidadania no contexto do direito humano que orientará o projeto de texto. É por essa razão que nossa proposta parte do contato com gêneros diversos (como relatos, notícias, canções, fotografias, documentos técnicos) e se encerra com a escrita literária. Por conseguinte, privilegia-se nesse percurso o trabalho com a intertextualidade, já tão postulado pelos documentos de educação:

A produção de discursos não acontece no vazio. Ao contrário, todo discurso se relaciona, de alguma forma, com os que já foram produzidos. Nesse sentido, os textos, como resultantes da atividade discursiva, estão em constante e contínua relação uns com os outros, ainda que, em sua linearidade, isso não se explicite. A esta relação entre o texto produzido e os outros textos é que se tem chamado intertextualidade. (BRASIL-MEC, 1998, p. 21)

(...) a ênfase que tem sido dada ao trabalho com as múltiplas linguagens e com os gêneros discursivos merece ser compreendida como uma tentativa de não fragmentar, no processo de formação do aluno, as diferentes dimensões implicadas na produção de sentidos. (BRASILMEC, 2006, p. 28)

Com base nessas considerações, percebe-se que o diálogo estabelecido entre a nossa proposta e algumas políticas educacionais pode dar margem seja a um encaixe curricular, que favoreça o cumprimento dos objetivos e dos conteúdos escolares obrigatórios, seja a um projeto extracurricular que contribua para a adoção "de estratégias mais dinâmicas, interativas e colaborativas em relação à gestão do ensino e da aprendizagem" (BRASIL-MEC, 2017, p. 12).

\section{PRÁTICAS EM EDUCAÇÃO E DIREITOS HUMANOS: OUTRAS FONTES}

Muitas das ações e políticas organizadas, no Brasil, por meio dos documentos oficiais mencionados até aqui também se aproximam dos apontamentos do Programa Mundial para Educação em Direitos Humanos (PMEDH), publicado pela ONU em 2005, com o objetivo de auxiliar, em tantos países quanto possível, a implantação de estratégias nacionais para o estabelecimento de práticas perpassadas pelos princípios da educação em direitos humanos. Estas envolveriam não apenas contextos escolares, mas também mecanismos de formação dos profissionais da educação e de diferentes atores sociais, de modo a promover mudanças culturais mais profundas. Nas palavras do plano:

Uma educação integral em direitos humanos não somente proporciona conhecimentos sobre os direitos humanos e os mecanismos para protegê-los, mas (...), além disso, transmite as aptidões necessárias para promover, defender e aplicar os direitos humanos na vida cotidiana. A educação em direitos humanos promove as atitudes e o comportamento necessários para que os direitos humanos de todos os membros da sociedade sejam respeitados. (PMEDH, 2005, p.1) 
Assim, para o PMEDH, é preciso pensar ações educativas de caráter prático, em que os participantes possam relacionar a perspectiva dos direitos humanos aos próprios contextos em que circulam, para que "se inspirem nos princípios dos direitos humanos existentes no seu próprio contexto cultural" (PMEDH, 2005, p.1). O programa estabelece diversos encaminhamentos para a concretização de práticas desse tipo no ambiente escolar, mas também ressalta a necessidade da participação dos mais diversos interessados em tal concretização, incluindo ONGs e instituições de pesquisa, como a universidade.

No Brasil, há uma série de iniciativas em curso que compartilham dessa perspectiva, seja na escolar, seja em contextos não formais de educação. Parte da inspiração para a proposta de ação aqui apresentada vem também de práticas como essas, a começar, por exemplo, da postura do Exame Nacional do Ensino Médio (ENEM) em sua prova de Redação. Desde sua criação em 1998, com o objetivo de mensuração do domínio, por parte dos concluintes do Ensino Médio, de competências e habilidades consideradas fundamentais a esse nível escolar pelo Ministério da Educação, o ENEM conta com uma prova de produção escrita que focaliza notadamente temas relacionados aos direitos humanos, tais como a relação entre o trabalho e a dignidade humana, a necessidade de convivência com a diferença, os desafios para a educação de pessoas surdas e a busca de ações de combate à degradação ambiental, à violência contra a mulher, às intolerâncias religiosas e ao racismo.

Desde 2009, o Exame tornou-se instrumento oficial de ingresso ao Ensino Superior em diversas instituições públicas de ensino e alcançou, em suas últimas edições, mais de 8 milhões de inscrições, garantindo grande visibilidade às questões abordadas pela prova. Merece destaque ainda o caráter propositivo da prova de redação desde a criação do Exame: além de argumentarem a respeito do tema a partir de seus conhecimentos, solicita-se, aos que prestam a prova, a elaboração de propostas de intervenção social que auxiliem na solução dos problemas ligados ao tema ${ }^{14}$.

14.Um exemplo de referência sólida que os professores de Língua Portuguesa poderiam tomar para o trabalho direitos humanos em sala de aula é a Cartilha do Participante - ENEM 2017, segundo a qual "determinadas ideias e ações serão sempre avaliadas como contrárias aos direitos humanos, tais como: defesa de tortura, mutilação, execução sumária e qualquer forma de 'justiça com as próprias mãos', isto é, sem a intervenção de instituições sociais devidamente autorizadas (o governo, as autoridades, as leis, por exemplo), incitação a qualquer tipo de violência motivada por questões de raça, etnia, gênero, credo, condição física, origem geográfica ou socioeconômica; explicitação de qualquer forma de discurso de ódio (voltado contra grupos sociais específicos)" (REDAÇÃO NO ENEM 2017, CARTILHA DO PARTICIPANTE, p. 10). Há, aí, exemplos de propostas que não poderiam estar de modo algum nas redações dos alunos, diretriz importante, embora ainda muito modesta para a complexidade de tratamento que a educação em direitos humanos demanda. 
Ao valorizar a indicação de diferentes agentes que possam atuar para amenizar os conflitos nesse sentido, o ENEM contribui com os objetivos do PMEDH, tais como a necessidade de "fomentar o entendimento de que cada pessoa compartilha a responsabilidade de conseguir que os direitos humanos sejam uma realidade em cada comunidade e na sociedade em seu conjunto" (PMEDH, 2005, p.9), reiterando a necessidade de pensar problemas que cronicamente afligem a sustentação dos direitos humanos, através de acontecimentos relevantes para o contexto brasileiro.

O ENEM restringe sua proposta ao gênero dissertativo-argumentativo, cujos procedimentos incluem a adoção de estratégias de impessoalização da linguagem, que demandam ao estudante certo afastamento de suas experiências pessoais e afetivas relacionadas ao tema. A própria dinâmica da preparação para exames vestibulares acaba, muitas vezes, promovendo processos de instrumentalização do ensino da escrita. Desse modo, esta proposta, no diálogo com as ações formativas ligadas à preparação para a prova do ENEM, apresenta pontos de aproximação (ao propor o tema ao âmbito do ensino da Língua Portuguesa) e distanciamentos (ao buscar abordagens que visam a construir espaços imaginativos para outras possibilidades de construção do pensamento e do uso das linguagens).

Fora do ambiente escolar formal, encontramos exemplos de articulação de estratégias que trabalham aspectos mais subjetivos e gerais acerca dos direitos humanos. Em museus que abordam o tema, há propostas de ação educativa que envolvem diversos tipos de atividades: visitas monitoradas, atividades especiais para grupos, trabalhos de campo, contação de estórias, rodas de conversa, produção de materiais de apoio didático ${ }^{15}$ etc. Para a proposta deste artigo, contribuíram, por exemplo, experiências de visitas aos espaços e/ou consulta dos materiais voltados a professores do Memorial da Resistência (em São Paulo), do Museo de la Memoria y de los Derechos Humanos (MMDH, em Santiago, Chile) e do Espacio Memoria y Derecho Humanos - Ex-ESMA (em Buenos Aires, Argentina).

A principal contribuição dos museus, acreditamos, é ênfase em pensar os direitos humanos no recorte das políticas de memória. Tal ponto é levantado como

15. Há propostas de atividades didáticas que podem ser realizadas fora dos espaços dos museus (em sala de aula ou outros locais) e conduzidas pelos professores. O MMDH dispõe material de orientação e apoio didático em sua página de internet (https://ww3.museodelamemoria.cl/recursos-educativos/) e também vídeos no canal do Youtube (https://www.youtube.com/user/museomemoriayddhh/ videos). O Memorial da Resistência oferece um kit didático, utilizando documentos de seu acervo para trabalho em aulas de história (material impresso distribuído para professores da rede pública da educação básica de São Paulo) e também mantém um canal de vídeos no Youtube (https://www. youtube.com/user/mresistenciasp). O Espacio Memoria y Derecho Humanos também possui um canal no Youtube com vídeos para uso institucional e educativo (https://www.youtube.com/user/ espaciomemoria). 
central no debate político contemporâneo por Andreas Huyssen, para quem os estudos sobre a memória deveriam "ligar-se de maneira mais robusta aos direitos humanos e à justiça, tanto em termos discursivos quanto práticos" (HUYSSEN, 2014, p. 196). A articulação entre direitos humanos e memória também se coaduna com a proposição geral de relacionar estória e história na construção de um pensamento político.

No $\mathrm{MMDH}$, as visitas guiadas para grupos escolares iniciam-se com um breve vídeo que brinca com a palavra memória em várias línguas e serve para iniciar uma conversa com os visitantes sobre os sentidos do termo em sua própria vivência. A partir disso, tais sentidos são tomados como fios que ajudam a costurar a visita aos espaços expositivos, onde se apresentam documentos, narrativas e imagens sobre as violações de direitos ocorridas no Chile entre 1973 e 1990 e sobre os movimentos de resistência da sociedade à ditadura de Augusto Pinochet.

O Memorial de Resistência e o Espacio Memoria y Derechos Humanos, por sua vez, são sítios de memória (ambos integram a rede internacional Sites of Conscience) montados em espaços que serviram de palco para experiências de violência política e violações de direitos. No caso, ambos foram locais de confinamento e tortura durante períodos das ditaduras militares em cada um dos países (DEOPS, em São Paulo, e ESMA, em Buenos Aires). A visita a esse tipo de espaço, além de permitir conhecer processos históricos, explora o caráter imaginativo da memória em termos sensoriais e emocionais: as visitas equivalem a experiências imaginativas, que "tornam o ausente presente" (estar ali agora remete a estar ali em outro momento passado), estimulando o visitante a sentir e pensar experiências que não as suas. $\mathrm{O}$ $\mathrm{MMDH}$ costuma também oferecer vários tipos de oficinas temáticas, como o "taller de arpilleras" (arpillera é uma técnica chilena de bordado, muito ligada à resistência de mulheres populares durante a ditadura) em que se propõe aos estudantes a produção de uma peça de modo que, enquanto costuram, conversem sobre a história política e cultural dessa prática de artesanato.

O Memorial da Resistência tem ainda um conjunto de materiais especiais, de caráter informativo e lúdico, para atendimento a visitantes surdos e aos com deficiências visual, mental ou motora. Nas visitas de grupos, os monitores costumam oferecer para os demais estudantes o manuseio desses objetos com os olhos vendados, por exemplo, simulando a perspectiva de uma pessoa cega.

Outras experiências que exploravam, de forma lúdica e interativa, atividades de "sair em visita" também foram exemplos que nos ajudaram a pensar nossa proposta. Citamos a atividade internacional itinerante nomeada "Museu da Empatia", na qual os visitantes eram convidados a andar por alguns minutos com um par de sapatos 
oferecido, enquanto escutavam um áudio gravado com a narração de uma estória protagonizada pelo dono dos calçados. (FOLHA DE S. PAULO, 2017)

\section{PRODUZIR ESTÓRIAS NA ESCOLA}

Apropriar-se da língua da narrativa é tanto uma necessidade psicológica, quanto antropológica, aponta Michèle Petit (2009): as experiências proporcionadas pela estória (lida, ouvida, escrita, assistida) teriam o potencial de "despertar em uma pessoa regiões silenciadas ou enterradas no esquecimento, dar-lhes forma simbolizada, compartilhada, e transformá-las" (PETIT, 2009, p. 105). A literatura no ambiente escolar deveria ser pensada, segundo essa autora, menos como um instrumento pedagógico e mais como o espaço para um tipo de liberdade, de permissão à imaginação para a reavaliação do self e dos laços de pertença em um mundo em constante desarranjo ("pare e pense").

De modo geral, pode-se asseverar que o eixo da literatura na educação básica (no Brasil e em várias partes do mundo) é voltado principalmente à formação do aluno como sujeito leitor ${ }^{16}$. Petit observa como os espaços mais significativos de escrita que ela encontrou em suas pesquisas (na França e em países da América Latina) são "de natureza extraescolar, nos quais não haja avaliação formal" (PETIT, 2009, p. 272), justamente pela dificuldade de criar dinâmicas pedagógicas escolares dissociadas da lógica do rendimento.

Os documentos curriculares brasileiros propõem que a leitura seja a chave para a exploração das potencialidades da literatura na ampliação das visões de mundo, porque esta seria capaz de propiciar experiências vicárias. Entretanto, apesar de relegada a segundo plano, defendemos que a capacidade de trabalho no campo da compreensão das alteridades, através da literatura, também pode ser realizada a partir da apropriação da escrita em sala de aula. Nesse sentido, faz-se premente discutir a importância das subjetividades nos atos de escritura, considerando as escassas reflexões acadêmicas sobre o papel do aluno no plano da criação e do exercício da imaginação. Enfatizam-se, nesse âmbito, os sentidos de escrita criativa e literária.

As definições de escrita criativa são, por vezes, difusas ou evasivas, e se proliferam, na internet, cursos e manuais a seu respeito, sem que se tenha clareza sobre qual é a abordagem da qual se parte. Bem por isso, é fundamental apontar

16.A existência da já consolidada teoria sobre o sujeito leitor da Academia Francesa é um exemplo revelador desse quadro, enquanto pouco se fala sobre o que se poderia chamar de sujeito escritor. 
algumas compreensões a esse respeito. Na concepção de Marcelos (2009), por exemplo, a escrita criativa:

consiste no estudo crítico, na transmissão e no exercício de técnicas utilizadas por escritores e ensaístas de diversas épocas e culturas, para a elaboração de textos literários (contos, novelas, romances, poemas, guiões, entre outros) ou não literários (artigos de jornal, reportagens, ensaios, etc.) (MARCELOS, 2009, p.13)

Complementando essa visão, Viegas (2015) assevera que, ao ponderar as dimensões complexas da escrita criativa, durante as oficinas que têm seu exercício como proposta central, ela seria considerada "a voz da imaginação estimulada", por meio da qual "aprende-se, sem preconceitos, experimenta-se, sem medo do erro, e dialoga-se, com autoconfiança" (VIEGAS, 2015, p.57). De modo semelhante, para Carnaz (2013) "a escrita criativa constitui uma das melhores formas de estimular os processos de pensamento, imaginação e divergência", a fim de que surja uma história.

Semelhantemente, em trabalho sobre a escrita criativa na sala de aula da Educação de Jovens e Adultos, Azevedo (2007), mencionando o ponto de vista do escritor Luiz Antonio de Assis Brasil, enfatiza que a escrita criativa

deve ser entendida como uma forma de ajudar cada indivíduo a desenvolver-se, a tornarse um ser consciente de si, do espaço que o envolve e dos outros, sendo assim capaz de experimentar, no contato com eles, emoções, percepções e sentimentos que formam o seu mundo interior. Neste sentido, ela partilha das intenções da finalidade geral da educação que é o desenvolvimento global da personalidade do indivíduo. (AZEVEDO, 2007, p.58-59)

Entre tais reflexões, destaca-se o trabalho de Catherine Tauveron, junto ao Instituto Nacional de Pesquisa Pedagógica de Paris, que revela articulações teóricas condizentes com nossa proposta pedagógica. Tauveron (2014) trata da forma como a escrita literária narrativa é costumeiramente trabalhada na escola, discutindo condições e obstáculos enfrentados nessa prática, propondo alternativas para promoção do encorajamento necessário aos alunos para que assumam a postura de autor. Para ela, "autor" é o aluno "que produz um texto narrativo com uma intenção artística", no que difere do "escritor", "um autor cuja intenção e o valor ou 'mérito' estético foram reconhecidos em um contexto social e histórico dado e que detém status oficializado" (TAUVERON, 2014, p. 88-89).

A fim de assumir tal postura, o aluno deve aproveitar sua experiência como leitor de literatura para escrever, além de assumir uma intenção artística ao imaginar o seu leitor-modelo. Assim, é possível notar que as ponderações da autora propõem um olhar particular sobre a relação entre leitura e escrita, de modo que a experiência da leitura literária não só ajude os alunos com os saberes narrativos 
formais, mas também com "os saber-fazeres pragmáticos" para que possam criar um texto que delega ao leitor a responsabilidade de se envolver, tanto afetiva como cognitivamente, na ficção criada.

No trabalho em sala de aula, Tauveron (2014) sugere ainda que seja promovido um novo pacto, no qual o aluno saiba que o texto, resultado de sua liberdade criativa, será objeto de apreciação e atenção estética de seus leitores reais - professores e pares -, por meio de uma leitura literária. Nesta, não são mobilizados apenas critérios formais de avaliação e julgamento, mas aqueles fundamentos próprios a um texto literário singular, exercício este que a autora resume na seguinte questão avaliativa: "O texto do par se deixa ler como um texto literário de autor, ele deixa ao leitor uma parte do trabalho e provoca um efeito de curiosidade, de suspense e de surpresa?" (TAUVERON, 2014, p. 90). Em suma, esse deve ser o propósito do ensino de escrita criativa literária a ser perseguido na escola.

No entanto, dentro de um processo extensivo, que leve à materialização do texto final, há etapas a serem seguidas, desde a verbalização do projeto de autor, através do incentivo ao compartilhamento dos projetos de escrita pessoais em sala de aula, a fim de convidar outros a se inspirarem, até a exploração de falhas na relação artística, com a verificação de quais intenções iniciais foram percebidas ou não pelo leitor, com a mediação do professor para averiguar se será necessária a reescrita ou o direcionamento da compreensão das intenções não observadas pelos alunos que se engajaram na leitura. Inclui-se, aqui, o ensino da reprodução dos comportamentos de grandes autores, destacando a escrita como processo preenchido com o movimento da reescrita, que é, por sua vez, repleto de rasuras, empréstimos e relações complexas entre realidade e ficção.

Essa reprodução abarca questões práticas, como a proposição de tarefas que fujam da banalidade e sejam estimulantes e originais, objetivando que os alunos possam incorporar à trama da história de ficção suas próprias experiências de leitura e seus conhecimentos escolares de outras disciplinas. Afinal, é isso que fazem os autores, embora essa noção não seja alvo de debate ou exposição aos alunos, fazendo com que eles mantenham uma relação de distância com a escrita, que consequentemente perpetua a ideia de que o domínio dessa prática não pode ser alcançado pelo seu exercício progressivo.

Como apoio a esses exercícios, Tauveron (2014) ainda recomenda que seja mantida uma caderneta de escritor para a autoprescrição de instruções por parte dos alunos. Desse modo, eles poderiam manter reunidos, num só espaço, seus projetos e ensaios de escrita inacabados ou em desenvolvimento e o material de apoio, documentado e recolhido para compor o universo que pretendem elaborar. 
Colecionariam, assim, objetos, pessoas e personagens que reflitam sensações relacionadas à construção narrativa. Caberia ao o professor chamar a atenção para as escolhas de escrita e seus respectivos efeitos nesse sentido.

Ademais, a autora reconhece que há dificuldades inerentes ao trabalho com a escrita literária em sala de aula, em relação às quais o professor tem um papel preponderante, porque a ele cabe, por exemplo, (i) o desmantelamento da representação do ato de escrever como um processo hierarquizado e linear, que é previamente planejado para só então ser posto em palavras, (ii) a proposição de tarefas mais complexas, em que se solicita que uma história seja escrita em sua totalidade, em substituição à execução de tarefas julgadas mais simples e parceladas, (iii) a capacidade de realizar as tarefas delegadas e de reescrever o texto problemático de maneira satisfatória e, por fim, (iv) a avaliação, em uma leitura que se aproveite das mesmas competências e olhar bondoso que lhe permite confrontar-se com a resistência das obras literárias legítimas.

Finalmente, partindo da reflexão de Marie-Claude Penloup (2007) acerca dos "conhecimentos ignorados" pela escola, Tauveron (2014) os define como conhecimentos adquiridos pelo sujeito escolar em sua experiência pessoal, mas que acabam por não se integrar ao "corpo de saberes socialmente reconhecidos e institucionalizados" (TAUVERON, 2014), sendo assim ignorados pelo próprio sujeito e/ou pela instituição escolar. Segundo Tauveron, Penloup se debruça "sobre os meios de identificar estes conhecimentos ignorados, de conscientizar os sujeitos e os envolver em um projeto de aprendizagem" (TAUVERON, 2014, p.100). Portanto, compreendemos que a escrita criativa pode ser incorporada a um projeto de aprendizagem que mobilize saberes acerca dos direitos humanos, em busca de uma verdadeira mudança de mentalidade dos sujeitos.

\section{PRODUÇÃO DE ESTÓRIAS E DIREITOS HUMANOS: APONTAMENTOS DE UMA PROPOSTA}

Como delinear, então, uma proposta que combine a produção de estórias e a educação em direitos humanos? Tentando contemplar uma resposta, propomos algumas orientações de trabalho com escrita narrativa e formação em direitos humanos dentro da disciplina de Língua Portuguesa, o que inclui algumas formulações pedagógicas mais gerais e indicações de um modelo didático para as atividades específicas.

Entendemos que o ensino em direitos humanos deve se apoiar em dois movimentos articulados, que acabam por sintetizar, na forma de ações, as concepções 
mais amplas contidas nos documentos educacionais sobre o tema: a sensibilização sobre as violações e o combate a todas as formas de preconceito. A palavra sensibilizar, aqui, não deve ser compreendida no sentido de uma fragilidade e vulnerabilidade frente ao mundo, no que se configuraria como representação de passividade; mas quase o contrário disso, como derivada de senso (sensus), ser capaz de perceber, saber e significar as coisas do mundo, ação materializada em uma postura voltada para a ação. Em síntese, a sensibilização relaciona-se ao desenvolvimento de um senso comunitário (sensus communis), da capacidade de julgar. Esta se faz pela combinação de uma compreensão racionalizada de processos históricos e sociais e da mobilização de paixões. Sensibilização e combate apontam, assim, para uma postura ativa; por mais que possamos entender os direitos humanos como um programa utópico, como afirma o historiador Samuel Moyn, eles são a principal ordem discursiva a mobilizar possibilidades de transformação na contemporaneidade, porque "evocam esperança e provocam ação". (MOYN, 2012, p. 1) $)^{17}$

Assim, educar para os direitos humanos é promover e estimular experiências com potencial de transformar consciências e atitudes, de modo que os objetivos de um programa em produção de estórias e direitos humanos devem ser, de acordo com nossa visão, os seguintes: (a) proporcionar espaços para refletir sobre experiências relacionadas a violações de direitos humanos por meio da escrita literária; (b) suscitar mudanças de percepção da alteridade e do sofrimento e sentimentos alheios, pelo jogo perspectivo que a literatura permite e (c) compreender alguns processos sociais vinculados a certos tipos de violações.

Para atingir tais objetivos, há alguns apontamentos estratégicos a se destacar. Considerando que, como afirmar Hunt, "os direitos humanos são difíceis de determinar porque sua definição, e na verdade a sua própria existência, depende tanto das emoções quanto da razão" (HUNT, 2009, p. 24), mais adequados serão métodos que possibilitem a combinação de aspectos cognitivos e afetivos. Essa articulação deve estar presente tanto na apresentação dos temas relativos aos direitos humanos, como na discussão sobre os respectivos processos históricos e componentes jurídicos, a fim de proporcionar espaços para a subjetivação, por meio das experiências imaginativas, tendo elas lastro biográfico e/ou ficcional. Nesse sentido, nem só o campo da compreensão objetivada deve ser estimulado nos alunos, nem só aquele da afetividade genérica e solidária, mas um equilíbrio entre ambos os tipos de conhecimento, como parâmetro para o processo de aprendizagem.

Além disso, ferramentas e caminhos para a análise de situações complexas e dilemas éticos podem ser propostos e devem ser evitadas qualificações simplificadas

17. "They evoke hope and provoke action." 
de processos e posturas. Em termos analíticos, não é aconselhável que os dilemas éticos sejam tratados em um campo de moralidade estrita - certo/errado; bem/mal - e nem de forma apriorística. A chave é refletir dentro das próprias contradições e nuances: um mundo que cria possibilidades de liberdade pode também criar cativeiros. As autoevidências podem enganar, portanto tudo está sujeito ao exame, a ser trazido para o confronto das experiências. Quanto às atitudes simplificadoras, Claudia Sotomayor, responsável pela ação educativa do MMDH do Chile, conta que nas visitas e trabalhos educativos do museu, os monitores são instruídos a não usar adjetivos "simplificadores" (moralizantes) para tratar de temas complexos ${ }^{18}$ : a ditadura chilena, por exemplo, não deve ser dita "terrível", a ação de agentes do Estado naquele contexto não é apresentada como "monstruosa" ou qualquer outra classificação assim. Em vez disso, é indispensável que dados concretos sejam mostrados e que o relato do fato histórico seja realizado, sem qualificações ou apagamento das contradições inerentes ao evento.

Também são fundamentais os múltiplos enfoques e a valorização da criatividade no uso da língua e no incentivo da compreensão do papel político das escolhas linguísticas, considerando a carga de significados que carregam certas expressões e itens lexicais. Acreditamos que mais eficaz será o processo de formação crítica (o alargamento de mentalidades), quanto mais variadas forem as fontes e abordagens que estimulam os debates e a realização das atividades, para que o discurso não fique preso em bolhas de autorreferências. Isso vale também para a escolha do uso da linguagem: é essencial não fixar nem controlar as escolhas de vocabulário; por um lado, porque a escrita literária deve ser uma atividade da criatividade, com infindáveis possibilidades de experimentação da linguagem, without banisters; por outro, porque o objetivo é abrir o campo de interlocução, uma vez que o programa não se volta à formação de ativistas ou militantes de causas específicas, mas a um processo de aprendizagem de um público muito heterogêneo.

Já que os direitos humanos são, muitas vezes, mal compreendidos, porque trabalhados com base em concepções genéricas, faz-se necessária a execução de atividades recortadas a partir de temas específicos e discussões de casos concretos. De acordo com essa perspectiva, é significativo não só o estabelecimento de vínculos com a realidade cotidiana dos alunos, mas também a proposição de pensar, junto deles, casos e eventos distantes de sua realidade cotidiana. Embora o privilégio do programa de formação em direitos humanos que discutimos neste artigo esteja dentro da disciplina de Língua Portuguesa, com destaque para a prática de escrita

18.Em fala no curso "Brasil e Chile: experiências de ações educativas em Memória e Direitos Humanos", realizado no Memorial da Resistência, São Paulo, jun. 2016. 
criativa e literária, é preferencial que enfoques interdisciplinares sejam postulados, uma vez que a articulação com outros campos do conhecimento não é apenas possível, como também desejável.

Cabe ressaltar que os direitos humanos, enquanto tema genérico, evocam ideais positivos, no entanto, as figuras associadas a eles são predominantemente negativas. Falar a esse respeito é tratar, em boa parte do tempo, das violações, trabalhar com imagens que representam aspectos sombrios da vida humana. Em termos psicológicos e cognitivos, consideramos ser necessário que se busque alternar, em alguma medida, essas representações com visões mais positivadas, como já afirmamos anteriormente. As experiências negativas são fundamentais no jogo imaginativo para a exploração desses temas, mas não é preciso recorrer exclusivamente a elas para compreender os processos e os personagens representados. Vítimas não são apenas vítimas em todos os aspectos de suas vidas, é central estimular a compreensão das existências multifacetadas de indivíduos e grupos humanos. E a ideia de "humanizar" passa justamente por isso, ver as experiências na sua diversidade e os indivíduos em sua profundidade - a complexidade no plano individual, a heterogeneidade no plano coletivo.

Todos os aspectos até aqui discutidos passam, em grande medida, pela relação professor-aluno. Em síntese, pode-se perceber que as atividades sobre direitos humanos são construídas sempre no reforço da perspectiva das vítimas, de modo que cabe à ou ao docente deixar isso claro, preferencialmente, de forma dialogada. O diálogo deve se estabelecer sobre bases que procurem não moralizar as conversas, sempre propondo mais a mudança de perspectiva do que a desqualificação de pontos de vista destoantes, valorizando a interatividade em todas as etapas do trabalho e afastando, na medida do possível, o silenciamento de perspectivas dentro da sala de aula.

Em termos didáticos, este programa permite que cada proposta de produção textual seja organizada na forma de oficinas extracurriculares, projetos temáticos interdisciplinares, roteiros de estudo ou atividades associadas a algum tópico de conteúdo curricular de Língua Portuguesa. Cada conjunto de atividades que visam à produção de um texto é chamada aqui de exercício de imaginação, em referência direta à proposta de Hannah Arendt em seus cursos. Assim, uma oficina, por exemplo, pode ser composta de um ou mais exercícios de imaginação e cada exercício pode ter extensões variadas na exploração do tema (mais ou menos etapas de desenvolvimento), a depender do tempo disponível, aprofundamento em cada tema e interesses específicos do/a professor(a) e da turma. 
O exercício de imaginação deve definir um tema, que propomos ser pensado a partir do direito e no diálogo com a Declaração Universal dos Direitos Humanos (DUDH, 1948). A ideia é selecionar um direito que se articule a algum dos artigos que compõem o texto da DUDH e/ou que possa lido à luz da proposição geral dessa declaração. Podemos pensar aqui em concepções de garantias de diversas naturezas (civis, sociais, políticos, difusas, de minorias etc.), ou ainda, concepções humanísticas e filosóficas que atravessam vários campos do direito. $\mathrm{O}$ atrelamento de temas a direitos fundamentais é importante para organizar o pensamento, segundo a ideia de construção de garantias para a cidadania, e para propiciar um aprendizado que permita entender o direito como um campo, não de verdades, mas de disputas e construções de sentidos.

Além dessa definição temática, propomos que cada exercício combine o tema a um sentimento ou emoção que permita aprofundar o trabalho de "sair em visita" e o jogo da subjetivação. Para permitir o encaixe com o tema principal (o direito), esses sentimentos devem se relacionar com a violação ou algum tipo de experiência de falta daquilo que o direito deveria garantir. Assim, o direito à moradia pode ser associado à saudade de casa, este mesmo sentimento pode também ser trabalhado em um exercício que trate a migração como um direito humano. Uma concepção como a de direito ao luto pode ser ligada à tristeza ou à incompletude; a noção penal de direito a julgamento justo, articulada ao desamparo; direito à saúde pode receber um tratamento que o vincule à autoestima. E assim por diante.

O direito selecionado pode ainda passar outro reenquadramento nas delimitações temáticas, aproximando-o a determinados tipos de ações de violação: o direito à moradia pode ser explorado a partir de experiências de remoções forçadas, o direito ao luto pela situação de familiares de desaparecidos ou ainda do enterro de indigentes, direito à saúde pode focar na loucura etc. O tema da memória pode ganhar, assim, o status de um subtema universal que pode ser ligado a qualquer recorte dentro do campo dos direitos humanos.

Todas essas balizas temáticas definem os parâmetros para o trabalho conceitual: a discussão no plano histórico e teórico. A ideia é que um conjunto de textos e fontes variadas possa ser oferecido e também que a pesquisa seja estimulada, para formar um arquivo conceitual. Quanto mais variedade com relação a gêneros, suportes, modalidades semióticas, procedências, esferas de circulação, campos disciplinares, abordagens nos textos que compõem esse arquivo, maior será o potencial aberto para o expediente criativo, além de maior contato com os parâmetros curriculares no que tange ao trabalho com gêneros e modalidades textuais variadas. Na medida do possível, a leitura dos textos que formam o arquivo deve ser interativa, com 
algumas propostas de atividades individuais e coletivas. Além de textos, o arquivo pode ser formado com outros tipos de fonte de informação, como visitas a museus ou outros tipos de espaços que tenham ligação com o tema, por exemplo, rodas de conversas, palestras, entrevistas etc. A partir desse arquivo conceitual, devem ser definidos os sinalizadores (em referência aos guide posts): eventos ou experiências mais particulares que deverão servir de parâmetros contextuais para a condução narrativa (experiências particularizadas pelas quais os personagens deverão passar).

Um dos trabalhos das alunas e dos alunos deverá ser o de produzir uma caderneta de escritor(a), conforme sugestão de Tauveron (2014), elaborada com atividades direcionadas a objetivos mais pontuais, relacionados principalmente ao desenvolvimento e planejamento textual. A finalidade da caderneta é associar dados sobre o contorno do exercício de imaginação a elementos mais fragmentados de construção narrativa, para a preparação da produção textual, em atividades progressivas. A caderneta é o momento de trabalhar conhecimentos um pouco mais utilitários de escrita: fornecer ferramentas para a escrita narrativa, mas já com alguma articulação com o recorte temático a ser trabalhado no exercício. Então, por exemplo, a multiplicidade de perspectivas, como proposta geral, pode ser explorada a partir de atividades sobre foco narrativo; temas que envolvam questões identitárias mais demarcadas podem pedir caminhos para aprofundar o trabalho com a caracterização de personagens; em uma atividade sobre os direitos da pessoa com deficiência, a caderneta pode trabalhar com atividades de descrição a partir de diferentes sensorialidades; uma proposta que trabalhe mais a fundo o tema da memória pode exercitar formas de organização dos planos temporais etc.

A outra função da caderneta de escritor(a) é a de servir como arquivo pessoal de pesquisa (além do arquivo conceitual fornecido pela professora ou pelo professor), um espaço de anotações, para guardar comentários, imagens, outras estórias, enfim, diversas formas de fragmentos que podem ajudar o estudante mais tarde a tecer a sua "teia de Penélope".

A proposta de produção textual propriamente condensaria os parâmetros trabalhados nas primeiras etapas do exercício de imaginação. A narrativa a ser escrita precisa ter enquadramento temático e trabalhar, quando possível, algum gênero textual relacionado ao tema (um exercício sobre migração pode propor o gênero carta; o direito ao luto, um obituário; uma discussão penal pode resultar na escrita de um diário de prisão etc.). A proposição baseia-se na criação de um ou mais personagens que passem pelas experiências dos eventos sinalizados (os sinalizadores indicados). Os personagens não devem ser caracterizados como grandes protagonistas das narrativas historiográficas ou jornalísticas sobre o evento, 
mas eles devem ser afetados e reagir emocionalmente a esse acontecimento. A ideia geral é a de refletir sobre a condição das vítimas de violações de direitos, o que não significa que, no plano narrativo, quem narra a estória deva ser obrigatoriamente a vítima. É possível construir um discurso que condene a violência a partir de um narrador que se caracteriza até mesmo como o agente de atos violentos, focar um personagem pelos olhos de outro, de modo a promover experiências de narração em múltiplos enfoques. Trabalhar a diferença entre discurso e narração pode ser bastante importante nessas reflexões sobre direitos humanos.

Propõe-se, ainda a elaboração de um projeto de texto no qual sejam feitas justamente algumas definições sobre tema, voz narrativa, caracterização de personagem, indicações de espaço e tempo. Durante a produção do projeto e do texto, o arquivo conceitual deverá ser consultado, na busca de informações que ajudem a construir parâmetros para a condução narrativa e as caracterizações (permitindo as escapadas entre estória e história). Após escrita e reescrita, propõese leituras coletivas dos textos, momentos que possam servir para o retorno às discussões mais conceituais, permitindo espaços para reavaliações (não apenas dos textos, mas de posicionamentos políticos, pessoais, afetivos etc.).

Por fim, cabe destacar que a seleção do(s) tema(s) de trabalho pode ser motivada por diversos fatores, como alguma questão contextualmente considerada imprescindível e/ou por uma consulta aos alunos e às alunas. Se possível, é recomendável que, na conversa inicial, sejam apresentadas algumas opções de temas e que a escolha seja feita, levando em conta as reações nessa ocasião. Vale considerar o perfil dos alunos e a estratégia que se pretende: caso se queira promover uma experiência mais intensa de alteridade, a opção por temas que partam de um distanciamento maior com o contexto dos estudantes será mais eficaz. Ressaltamos que temas relacionados aos direitos humanos tendem a mobilizar uma forte carga emotiva e, se estiverem relacionados a um tipo de violação muito próxima ao universo dos alunos e das alunas, podem gerar reações fortes, movimentar questões traumáticas, o que evidencia a necessidade de preparação de um diagnóstico preliminar.

\section{PALAVRAS FINAIS}

O objetivo central de nossos esforços até aqui foi o de demonstrar viável a constituição de um caminho bastante específico para o trabalho com direitos humanos em aulas de Língua Portuguesa do Ensino Básico. Tomamos as atividades de escrita literária de textos narrativos como oportunidade para, à luz de Hannah 
Arendt, propiciar aos estudantes a experiência vicária de sair em visita ao Outro. Mais do que apenas uma atividade utilitária, mais do que mera empatia ou benevolência comedida, a forma de reconhecimento que se supõe alcançável por meio de propostas assim parece aproximar-se do âmago da sensibilização de que tanto se fala, uma vez que a ancora nas experiências pessoais do próprio sujeito escritor, ao invés de, como é usual, ignorá-las de todo.

Na realidade, o que propusemos - com todas as limitações de escopo e de aprofundamento - nada mais é do que a possibilidade de experimentar o Outro sem perder-se de si. Trata-se, pois, de um privilégio, uma vez que, como escreve José Eduardo Agualusa em seu romance, "todos podemos, ao longo de uma vida, conhecer várias existências. Eventualmente, desistências. Aliás, o mais habitual. Poucos, contudo, têm a possibilidade de vestir uma outra pele" (AGUALUSA, 2012, p. 45). Acreditamos, portanto, que, no contexto das atividades sugeridas, o valor da escrita de estórias não está meramente em seu produto (o texto em si mesmo), mas, sobretudo, em seu processo, como teia. Um "vestir" fundamentado, afinal, nessa identificação de si e do Outro, na tessitura de uma pele sobre a outra.

\section{$\overline{\text { REFERÊNCIAS }}$}

AGUALUSA, J. E. (2012). Teoria Geral do Esquecimento. Lisboa: Dom Quixote.

ALVES, J.A.L. (2013). Os direitos bumanos na pós-modernidade. São Paulo: Perspectiva.

ARENDT, H. (1972). Entre o passado e o futuro. Tradução de Mauro W. Barbosa de Almeida. São Paulo: Perspectiva.

ARENDT, H. (1987). Homens em tempos sombrios. Tradução de Denise Bottmann. São Paulo: Companhia das Letras.

ARENDT, H. (1994a). Lições sobre a filosofia política de Kant. Tradução de André Duarte de Macedo. Rio de Janeiro: Relume-Dumará.

ARENDT, H. (1994b). Rabel Varnbagen: uma judia alemã na época do Romantismo. Tradução de Antônio Trânsito e G. Kludasch. Rio de Janeiro: Relume-Dumará.

ARENDT. H. (1994c). We Refugees. In: ROBINSON, M. (ed.). Altogether Elsewhere: Writers in Exile. Boston/London: Faber and Faber, p. 110-119. 
ARENDT, H. (1995). A vida do espírito. Tradução de Antonio Abranches e Helena Martins. Rio de Janeiro: Relume-Dumará.

ARENDT, H. (2005). A condição bumana. Tradução de Roberto Raposo. Rio de Janeiro: Forense Universitária.

AZEVEDO, C. S. (2007). Escrita criativa em sala de aula do EJA - Efeitos sobre a produção textual dos alunos. Dissertação (Mestrado em Educação). Faculdade de Educação, Universidade Federal de Pelotas, Pelotas.

BOBBIO, N. (2004). A era dos direitos. Tradução de Carlos Nelson Coutinho. Rio de Janeiro: Elsevier.

BRASIL-MEC (1998). Parâmetros curriculares nacionais: $3^{0}$ e $4^{0}$ ciclos do ensino fundamental - Língua Portuguesa. Brasília: MEC/SEF.

BRASIL-MEC (2006). Orientações Curriculares para o Ensino Médio - Volume I: Linguagens, códigos e suas tecnologias. Brasília: MEC/SEB.

BRASIL-MEC (2013). "Diretrizes Nacionais para a Educação em Direitos Humanos" PARECER CNE/CP No 8/2012, in.: Diretrizes Curriculares Nacionais Gerais da Educação Básica. Brasília: MEC/SEB, pp. 494-513.

BRASIL-MEC (2017). Base Nacional Comum Curricular - Educação é a Base. Brasília: MEC/SEB.

BRASIL-MEC (2018). Base Nacional Comum Curricular - Ensino Médio. Brasília: MEC/SEB.

BRASIL-SDH (2013). Caderno de Educação em Direitos Humanos: Diretrizes Nacionais. Brasília: $\mathrm{SDH} / \mathrm{PR}$.

BRASIL-SEDH (2003). Plano Nacional de Educação em Direitos Humanos. Brasília: Secretaria Especial dos Direitos Humanos; Ministério da Educação.

BRASIL-SEDH (2010). Programa Nacional de Direitos Humanos (PNDH-3). Brasília: SEDH/PR.

BRASIL (1996). Lei n. 9.394, de 20 de dezembro de 1996. Estabelece as diretrizes e bases da educação nacional. D.O.U. de 23 dez. 1996.

BRASIL, L. A. A. (1991). Invenção e Construção Literária: O Eterno debate. Leitura no Brasil. São Paulo: Editora Ática. 
CARNAZ, M.E. A. R. (2013). Da criatividade à escrita criativa. Dissertação (Mestrado em Didática da Língua Portuguesa). Instituto Politécnico de Coimbra, Escola Superior de Educação, Coimbra.

FOLHA DE S. PAULO. MENON, I. (2017). Pessoas calçam sapatos de outras em exposição que promove a empatia. 2017. Disponível em: <http://www1.folha.uol.com.br/ ilustrada/2017/11/1936746-pessoas-calcam-sapatos-de-outras-em-exposicao-quepromove-a-empatia.shtml>. Acesso em 5 fev. 2018.

HUNT, L. (2009). A invenção dos direitos bumanos: uma história. Tradução de Rosaura Eichenberg. São Paulo, Companhia das Letras.

HUYSSEN, A. (2014). Culturas do passado-presente: modernismos, artes visuais, políticas da memória. Tradução de Vera Ribeiro [Coordenação de Tadeu Capistrano]. Rio de Janeiro: Contraponto/Museu de Arte do Rio.

KOHN, J.; YOUNG-BRUEHL, E. (2006). Hannah Arendt on Action and Violence with Reference to Simone Weil and Rachel Bespaloff on Homer's Iliad: A Conversation. In: BENFEY, C.; REMMLER, K. (orgs.). Artists, Intellectuals, and World War II: The Pontigny Encounters at Mount Holyoke College, 1942-1944. Boston: University of Massachusetts Press. pp. 220-239.

KRISTEVA, J. (2001). Hannab Arendt, life is a narrative. Tradução de Frank Collins. Toronto: University of Toronto Press.

LAFER, C. (2007). Experiência, ação e narrativa: reflexões sobre um curso de Hannah Arendt. Estudos Avançados, São Paulo, v. 21, n. 60, p. 289-304.

MOYN, S. (2012). The Last Utopia: Human Rights in History. Cambridge: Harvard University Press.

PETIT, M. (2009). A arte de ler ou como resistir à adversidade. Tradução de Arthur Bueno e Camila Boldrini. São Paulo: Ed. 34.

PMEDH (2007). Programa Mundial para a Educação em Direitos Humanos. Escritório do Alto Comissariado das Nações Unidas para os Direitos Humanos e Organização das Nações Unidas para a Educação, a Ciência e a Cultura.

RÜSCHE, A.; MASCARO, L. D.M. (2015). Tornar presente o ausente: escrita criativa e reflexão sobre Direitos Humanos. Lua Nova, São Paulo, n. 96, p. 71-87. 
STERN, P.; YARBROUGH, J. (1978). Teaching: Hannah Arendt. The American Scholar, v. 47 , n. 3, pp. 371-381.

TAUVERON, C. (2014). A escrita "literária" da narrativa na escola: condições e obstáculos. Educar em Revista, Curitiba, n. 52, p. 85-101.

VIEGAS, A.M.L. (2015). Contributos da Leitura Recreativa e da Escrita Criativa para o Processo de Ensino-Aprendizagem de Português Lingua Estrangeira. Dissertação (Mestrado em Português Língua Não Materna - Língua Estrangeira/ Língua Segunda). Instituto de Letras e Ciências Humanas, Universidade do Minho.

YOUNG-BRUEHL, E. (1977). Hannah Arendt's storytelling. Social Research, v. 44, n. 1, p. $183-190$.

Recebido: 11/03/2018

Aceito: 18/06/2018 